\title{
Postmodernity in Contemporary Chinese Poetry: Taking YU Jian's Poetry as an Example*
}

\author{
QIU Shi-cun \\ Sichuan University of Arts and Science, \\ Dazhou, China
}

\author{
QIU Jia-cun \\ Guangdong College of Business and Technology, \\ Zhaoqing, China
}

\begin{abstract}
Postmodernism has given great influence to the literary creation and criticism of contemporary Chinese literature. Although postmodern poetic writing appears even earlier than postmodern novels, postmodern poetic criticism has not gotten enough attention. As a matter of fact, YU Jian, as one of the most important representatives of contemporary Chinese poetry, has created many postmodern poems which deconstruct traditional poetry with constructional purpose. Contemporary poets like YU reject metaphorization and symbolization and at the same time look for an original way of expression without metaphors and symbols so as to highlight vigorous common life not with artistic sublimation but with aestheticization of common life.
\end{abstract}

Keywords: postmodernity, contemporary Chinese poetry, YU Jian, aestheticization of common life

\section{Introducion}

Chinese postmodern writing and criticism arose from 1980s and in 1990s postmodern criticism seemed to be an authoritative discourse, though the focus was mainly on novels. However, contemporary Chinese poets practiced postmodern writing earlier: the poetic group of "Them" "had an avantgarde inclination of deconstruction in postmodern literature" (LIANG, 1998, p. 58). Literary histories have paid attention to postmodernity of contemporary Chinese poems: Chinese Literary History of the 20th Century thought that "the appearance of the new generation marks the second change of aesthetic concepts and skills of the New Period's poems and it may be considered as a primary impact and attempt of 'postmodernist' culture and arts" (KONG, 1997, p. 1450). Later, Chinese Modern Literary History: 1917-1997 (Vol. II) does not deny the exploratory meaning of postmodernist poetry of the Third Generation, but at the same time, the book criticizes that "without extensive study on Chinese and Western history, reality and artistic tradition", this kind of poetry "borrows Western postmodernist philosophy and literary trend and even takes it as the criterion" and "indiscriminately considers thousands of years of national and cultural mentality, moral ideal, and artistic aesthetic standards all as the revolting targets" (ZHU, DING, \& ZHU, 1999, pp. 200-201). This can be taken as a counterevidence of

\footnotetext{
* Acknowledgements: Supported by Chongqing program of postgraduate innovative research: Comparative study on postmodernist poems of the Third Generation and the Beat Generation (CYB14065).

QIU Shi-cun, lecturer at School of Foreign Language, Sichuan University of Arts and Science; Ph. D. candidate at Modern Chinese Poetry Research Institute, Southwest University.

QIU Jia-cun, teaching assistant, MBA, School of Foreign Language, Guangdong College of Business and Technology.
} 
Chinese postmodernist poetry. Then, Chinese Contemporary Literary History pointed out that in early 1980s HAN Dong had already used "zero-degree writing" which later prevailed in late 1980s' literature and especially his poem "About Da-Yan Pagoda" written in 1982 "has already been a narrative mode of Chinese postmodern poetry" (TIAN, 2003, p. 417). In an era of criticism diversification, the above expressions on postmodernity of contemporary Chinese poetry should be taken seriously. This paper aims to point out that $Y U$, as one of the most important representatives of contemporary Chinese poetry, has created many postmodern poems which deconstruct traditional poetry with constructional purpose.

\section{YU Jian's Ideas on Postmodernity}

YU has his own deep understanding on postmodernity. Linking to the old Chinese aesthetics that "In heaven and earth there is holy beauty which, however, is not put into words", YU thinks that postmodernity is "in fact a tendency returning to the tradition of "concreteness"” (2004, p. 18) and means "deconstruction on metaphorical system of language", "the process of which is language restoration and naming conduct" (2004, p. 20). In his literary diary, YU once said:

Postmodernity is "an art of ideology," which is the prelusion of revolution even revolution itself...Theory of evolution prevailing in the 19th century has already been doubted as one more forward step is only "clon", but in the East it is still taken as criterion. So the appearance of postmodernity may also be a reaction to theory of evolution. I dare to say that the traditional Chinese thoughts are some kind of "postmodernity"...as they all the time take earth and life as arts...I am inclined to consider postmodernity as a humorous way to observe the world and sometimes express your humorous understanding. (2004, p. 63)

In the West, postmodernity is always associated with modernity. The former is either deconstruction or development of the latter. According to YU, in contemporary Chinese culture, modernity is some kind of "compulsive subjectivity" and "pseudo-deepness" and what postmodernity does is "deconstruct them to create real deepness which does not appear at all in contemporary Chinese culture" (YU, 2004, p. 168); therefore, "postmodernity in China is not replication but deconstruction" and what it deconstruct "is not deepness but pseudo-deepness so as to construct the real deepness and meaning" (YU, 2004, p. 168).

\section{Aestheticization of Common Life}

Postmodernity is "aestheticization of common life" which means "the breakdown of artistic sublimation" (Yip, 2004, p. 28). "Aestheticization of common life" is the focus of YU's postmodern poems which, expressing cultural interests of common people, is an original representation of common life and a deconstructive transcendence to modern "Misty Poetry" which aims to establish spiritual and rational idols with grand narratives. In this way, YU rejects metaphorization and symbolization and at the same time looks for an original way of expression without metaphors and symbols; his purpose of poetic creation is to highlight vigorous common life not with artistic sublimation but with "aestheticization of common life".

\section{Rejecting Metaphorization}

Rejecting metaphorization is to "reject metaphorical supremacy of general discourse", which means "to restart the naming function of poetry"; "in this new naming process which uncovers those metaphorical names, poetry emerges" (YU, 1997, p. 246). To YU, Chinese language, especially mandarin, has metaphorical 
supremacy which has covered the real truth of the concrete world. Therefore, what he does is to show concreteness of things themselves in the process of uncovering those existing names. His poem "To Name a Raven" (YU, 2013a, pp. 224-227) is an impressive experiment of this kind. In the context of history and culture, a raven has not already been the bird flying in the sky or hoping on the land, but a sign, a metaphor, or a myth. However,

when a raven perches on the wild of my heart/what I want to say is not its symbol, its metaphor or myth/what I want to say is the only raven, just like in that year/I did never catch a pigeon in a ravel nest. (YU, 2013a, p. 224)

As a matter of fact, the poet is not to rename a raven; he has just bravely represented the raven itself with no imposed concepts: "I just want to say something/to show the world that I am not afraid/of those invisible sounds" (YU, 2013a, p. 227). This process of uncovering is one to restart and reach the thing itself. "I come, I see, I speak" (YU, 1997, p. 1).

The long poem "Zero File" (YU, 2013a, pp. 196-210), written in 1992 and published on The Master in 1994, once aroused great impact and controversy. It parodies the writing mode of a file, that is, to "parody in the poet's tone some existing discourse and tease it ironically" (YU, 2004, p. 62). In this poem, the life of a 30-year-old man is presented with several periods, such as birth, growth, love, and daily life; the man's situation is portrayed in the special historical context of "the Great Cultural Revolution" to show the basic and absurd connection between individual life and public discourse. Once a man is born, he is put into public discourse like the file. "Zero File" piles up trivial and tedious words, numbers, or pictorial fragments to impress the reader strongly depressive feelings; it is a cruel but real portrayal that the file is all-pervasive to control the individual life in that special context.

His bag of his 30 -year life, the one of 1800 locker's bags/is controlled by a key/not so thick but a little more than 50 pages 40000 words, as the man is young/in addition to over 10 common seals, 7 or 8 photos, some fingerprints. Net weight, 1000 gram. (YU, 2013b, p. 196)

Connecting literary imagination with scientific and specific numbers, YU vividly shows the file's disciplining and controlling on the individual and the depression of metaphorical and ideological discourse like the file.

Originally, the file exists as record and evidence of a person's existence; consequently, a person, parasitical on words, becomes a shadow of his file and has to discipline him according to the rules approved in the file: "Some words make him public and some words conceal him. Following the words from simple to multifarious, from/shallow to deep, from/naive to mature, from/clumsy to sophisticated" (YU, 2013b, p. 198); the person comes to be a body without feelings and sensation. Anyway, with the poem YU practices, extensively and deeply, his writing principle: to write a poem of "specific, partial, fragmental, detailed, unofficially historical, reducing the old system of value and metaphor till to zero" (YU, 1997, p. 250), as "the subject of the poem is not a person himself but some 'specific, partial, fragmental, detailed, unofficially historical' words and things which portray a real history of a man's growth" (CHEN, 2004, p. 177). The whole poem's parody to the ideological discourse of the file reaches the climax in the last section, which gives an extremely detailed and clear statement on how to make and keep the file and accordingly has a strong ironic effect on absurdity of that special social context. However, in a culture full of metaphors and symbols, the public often turn a blind eye to this kind of "real history" 
which needs "the poet from the Inferno" to point out; it is in this situation that YU once said sadly: "I find that I live in such an age that the more explicit you said, the more the public do not understand... The puzzlement and misunderstanding deepens out of my clearness" (YU, 1997, p. 285).

\section{Highlighting Original Oral Language}

Rejecting metaphorization and subverting sublimity to set up postmodern poetic creation principle of "aestheticization of common life" has to be realized through language. As the most profound part of cultural accumulation, written language embodies the deepest cultural tradition of metaphorization and symbolization. Anyway, it needs to reject using too much written language and pay more attention to original oral language which has not been immersed so much in metaphors and symbols. Only in this way can a poet reach life itself directly. As to YU, "in written language which is the mortuary of poetry, there is only suffocation and death and so poetry does not come from it"; "oral language is the foundation of poetry, and right on this foundation, poetry generates many different styles, produces variety of language sense and then form special poems" (YU \& XIE, 2003, p. 111).

Indeed, oral language has an irreplaceable place in YU's poetic concept. It is through oral language that his poems like "No. 6, Shangyi Street" help to initiate the oral poetic style of one generation. To YU, oral language is the breath of the poet's heart and soul, and what it expresses is language sense of life itself. YU's poems have a calm and narrative tone with no metaphorization or symbolization. In "Thanks Father" (YU, 2013c, pp. 262-264), the poet displays the father's much carefulness and obedience with simple words:

In 1957 you became a father/As a good man, dad, you lived a hard life/admitting, exposing, disclosing and narking/After finishing all these things you get off work, bag under oxter/At night you is not able to fall asleep, always listening carefully/and you often get up quietly to examine son's diaries and sleeping words/...for the brat will incriminate his families if he say some bad words. (YU, 2013c, p. 263)

In another poem "The lid of a Beer Bottle" (YU, 2013d, pp. 194-195), YU speaks out his language sense with the simplest words and the commonest thing:

I don't know what to call it.../It is a waste: its whiteness is only its whiteness and its shape is only its shape/.../At that moment, I haven't drink yet and it's me who open the beer bottle/and so I see that it jump out so strangely, gone so easily/I suddenly want to be like it, to jump out with a simple sound "PENG", but I can't/It's hard and dentoid edge cuts my finger/which makes me feel kind of sharpness with no connection with a knife. (YU, 2013d, p. 194)

It is an unimpressive waste (a lid of a beer bottle) that gives the poet "sharp" sense of life existence. In fact, to highlight this oral language full of life senses is associated with YU's cognizance to his social location: "I belong to 'the generation standing by the dinner table.' God arranges me to be an outlier and so I have been used to be overlooked by the era and those experienced people" (TANG \& WANG, 1987, p. 153). This cognizance of "an outlier" gives the poet a distance to observe the world more clearly and precisely.

As a writing mode and style, oral language has one more meaning. It is a "soft" tendency of Chinese language, which rejects the stifling pressure of the "hard" language of mandarin. In YU's understanding, as modern Chinese language emphasizes ideology and metaphysical thinking more and more, it gets to become harder and harder out of excluding the concrete world of life, and so it is not proper to express the present, instant, soft and specific common world and life. It is oral language that restores the connection between common sense 
and concrete things. Right from the beginning, poetic creation with oral language is far from the ideological center (YU, 2004, p. 158). In this way, oral language has a deconstructive function to the written language of metaphorization and symbolization.

\section{Conclusion}

To sum up, postmodernism has given great influence to the literary creation and criticism of contemporary Chinese literature. Postmodern poetic writing appears even earlier than postmodern novels. Contemporary poets like YU reject metaphorization and symbolization and at the same time look for an original way of expression without metaphors and symbols so as to highlight vigorous common life not with artistic sublimation but with "aestheticization of common life".

\section{References}

CHEN, Z. J. (2004). Comments on poets in both sides of the Taiwan Straits. Nanning: Guangxi People's Publishing House. KONG, F. J. (1997). Chinese literary history of the 20th Century (Vol. I). Ji'nan: Shandong Press of Literature and Arts.

LI, Z. Q. (1997). Modern poetry: Special "knowledge" on existence, history, discourse of individual life—interviewing with CHEN Chao. In Comment on Academic Thinking (Vol. II). Liaoning: Liaoning University Press.

LIANG, Y. (1998). On poetic trend of contemporary Chinese poetry. Shenyang: Spring Press of Literature and Arts.

TANG, X. D., \& WANG, J. X. (Eds.). (1987). Selected experimental contemporary Chinese poems. Shenyang: Spring Press of Literature and Arts.

TIAN, Z. Y. (2003). Chinese contemporary literary history. Changsha: Hunan Normal University Press.

Yip, Wai-Lim. (2004). Yip Wai-Lim's collected works: Thinking on modern and postmodern living space and cultural space (Vol. V). Hefei: Anhui Educational Press.

YU, J. (1997). Diaries in the notebook with Brown Leather. Beijing: Oriental Publishing Company.

YU, J. (2004). Rejecting metaphorization: Diaries, comments and interviews. Kunming: Yunnan People's Publishing House.

YU, J. (2013a). To name an raven. In I Say What I See: YU Jian's Collected works (1982-2012). Beijing: China Writers Publishing House.

YU, J. (2013b). Zero file. In I Say What I See: YU Jian's Collected works (1982-2012). Beijing: China Writers Publishing House.

YU, J. (2013c). Thanks father. In I Say What I See: YU Jian's Collected works (1982-2012). Beijing: China Writers Publishing House.

YU, J. (2013d). The lid of a beer bottle. In I Say What I See: YU Jian's Collected works (1982-2012). Beijing: China Writers Publishing House.

YU, J., \& XIE, Y. X. (2003). Dialogue between YU J. and XIE Y. X.. Suzhou: Suzhou University Press.

ZHU, D. L., DING, F., \& ZHU X. J. (Eds.). (1999). Chinese Modern Literary History: 1917-1997 (Vol. II). Beijing: Higher Educational Press. 